\title{
How Phages Overcome the Challenges of Drug Resistant Bacteria in Clinical Infections
}

This article was published in the following Dove Press journal:

Infection and Drug Resistance

\author{
Majid Taati Moghadam' \\ Nour Amirmozafari ${ }^{1}$ \\ Aref Shariati ${ }^{1,2}$ \\ Masoumeh Hallajzadeh (D) ${ }^{\prime}$ \\ Shiva Mirkalantari ${ }^{1}$ \\ Amin Khoshbayan 1,2 \\ Faramarz Masjedian Jazi ${ }^{1,3}$ \\ 'Department of Microbiology, School of \\ Medicine, Iran University of Medical \\ Sciences, Tehran, Iran; ${ }^{2}$ Student Research \\ Committee, Iran University of Medical \\ Sciences, Tehran, Iran; ${ }^{3}$ Microbial \\ Biotechnology Research Center, Iran \\ University of Medical Science, Tehran, \\ Iran
}

\begin{abstract}
Nowadays the most important problem in the treatment of bacterial infections is the appearance of MDR (multidrug-resistant), XDR (extensively drug-resistant) and PDR (pan drug-resistant) bacteria and the scarce prospects of producing new antibiotics. There is renewed interest in revisiting the use of bacteriophage to treat bacterial infections. The practice of phage therapy, the application of phages to treat bacterial infections, has been around for approximately a century. Phage therapy relies on using lytic bacteriophages and purified phage lytic proteins for treatment and lysis of bacteria at the site of infection. Current research indicates that phage therapy has the potential to be used as an alternative to antibiotic treatments. It is noteworthy that, whether phages are used on their own or combined with antibiotics, phages are still a promising agent to replace antibiotics. So, this review focuses on an understanding of challenges of MDR, XDR, and PDR bacteria and phages mechanism for treating bacterial infections and the most recent studies on potential phages, cocktails of phages, and enzymes of lytic phages in fighting these resistant bacteria. Keywords: bacteriophage, drug resistant, MDR, XDR, PDR
\end{abstract}

\section{Introduction}

Reports of scientific studies suggest that the development of antibacterial drugs is lagging behind the emergence of antibacterial resistance profile, especially for major bacterial pathogens. ${ }^{1,2}$ Several antibacterial resistance profiles have been detected recently including the multidrug-resistant (MDR), extensively drugresistant (XDR) and pan drug-resistant (PDR) phenotypes. ${ }^{3-6}$ Accordingly, the human health and efficiency of commonly used antibiotics are threatened seriously by MDR and XDR bacteria. Studies showed that at least 25,000 patients die each year in the European hospitals from an infection due to MDR bacteria. ${ }^{1-6}$ Furthermore, the mortality rate for patients infected by XDR organisms is reported to be over 50 percent, which has led to increased healthcare costs. ${ }^{1,2,4-6}$ The impacts of resistant infections to healthcare costs are estimated at about $\$$ 20 billion yearly and they also result in 8 million additional hospital days in the United States. ${ }^{7-9}$ Furthermore, over 30 percent of pharmaceutical budgets of hospitals in the United States is spent on antibiotics. Methicillin-resistant Staphylococcus aureus (MRSA) is an antibiotic-resistant agent, which poses a remarkable threat to the health care by causing $\sim 19,000$ deaths and a cost of \$3-4 billion annually in the US. The number of cases influenced by MDR, XDR, and PDR Gram-negative bacteria, such as Acinetobacter baumannii, Escherichia coli, Klebsiella pneumoniae, Pseudomonas aeruginosa, as well as MDR or XDR
Correspondence: Faramarz Masjedian Jazi Department of Microbiology, School of Medicine, Iran University of Medical

Sciences, Tehran, Iran

Tel +989/23905926

Email Masjedian.f@iums.ac.ir 
isolates of Mycobacterium tuberculosis has been growing continuously in recent years. The inherent genetics and physiology transmitted vertically across species, and the bacteria's tendency for exchanging different genes horizontally among species and genera have been suggested as the possible causes of antibiotic resistance in these bacteria. $^{7-9}$ The limitation of current clinical options for confronting threats of infections caused by intricate pathogens has led to a critical problem that promotes researchers to discover new approaches to face the growing problem of bacterial MDR, XDR, and PDR. Although different management strategies have been implemented for combating resistant pathogens, such as (a) comprehensive understanding of the nature of resistance in terms of molecular basis, evolution, and dissemination; (b) finding new chemical agents that have antibiotic properties; and (c) enhancing the efficiency of antibiotics using innovative techniques, such as combination therapy, increasingly resistant bacteria are on the rise. Accordingly, alternative approaches are required to control resistant pathogens. Bacteriophage (phage) is an example of such management strategies. ${ }^{10-13}$ Bacteriophages are specific viruses naturally influencing the bacteria that have been used as therapeutic agents for bacterial infections. Using phages as antibacterial agents for pathogenic bacteria, known as phage therapy, was first introduced approximately 90 years ago. The basis of this treatment is binding of a phage to bacterial cells and causing rapid lysis of the cells. ${ }^{14}$ Considering the background of rising antibiotic resistance and decreasing number of new antimicrobial components, phage therapy as a novel safe strategy seems attractive for the following reasons: the phage and antibiotic resistance have different mechanisms of action; their effects are limited to the site of infection with no effect on their surrounding cells such as eukaryotic cells, and they can be easily isolated from several environments. ${ }^{14}$ In the last decade, supporting evidence is provided worldwide to help establish the efficacy of bacteriophages in combatting the challenges posed by MDR, XDR, and PDR bacteria, and even show the ability of bacteriophages to replace antibiotic treatments. ${ }^{15-18}$ This review focuses on the challenges in the conventional treatment of MDR, XDR, and PDR bacteria and the mechanisms by which phages may help to treat such infections. The most recent studies on the potential of phages, phage cocktails, and the enzymes of lytic phages in fighting these resistant bacteria are included in this review.

\section{History of Phage Therapy}

The presence of a biological source in the water of an Indian river that changes the cultures of cholera-inducing bacteria was first discovered in 1896 by a British bacteriologist, Ernest Hanbury Hankin. ${ }^{19}$ His experiment may be the first discovery of bacteriophage activity. The probable destruction of bacteria into granules through transparent materials present in pure cultures was later realized by Frederick Twort while he was working on the growth of vaccinia virus. ${ }^{20}$ Further supporting reports for these experiments were provided by Felix d'Herelle who described his finding as "antiShiga microbe" which was detected during filtering stools of patients suffering shigellosis. Twort and d'Herelle were curious about the agent causing bacterial lysis and questioned if the destroying agent was a bacterial virus. However, at the time, d'Herelle believed that the observed microbe was a "veritable" microbe of immunity and an obligate bacteriophage. ${ }^{21}$ Unfortunately, Twort was not able to continue his investigation in this field, because of some reasons, such as funding shortages and his enrolment in the Royal Army Medical Corps. Nevertheless, d'Herelle started to treat bacterial infections in humans, which resulted in publication of many articles based on non-randomized trials worldwide. Then, he recommended intravenous phage for the treatment of invasive infections and presented a summary of all his findings and observations in $1931 .^{21-23}$ Following these works, the idea of phage attracted the microbiologists' attention and soon the phage therapy played a pivotal role in the development of medicines. Tracing the progression of phage biology shows that this field started with an enthusiastic period associated with excessive and often unrealistic claims with a limited understating of the viral nature of phages or their strengths and limitations. ${ }^{24,25}$ Phage therapy and its active application continued to develop in the Soviet Union and Eastern Europe in the 1940s. In the West, the development of molecular biology based on phage therapy in its golden age was limited to the intensive work on just a few phages infecting a virulent strain of E. coli. ${ }^{14,26}$ Finally, thanks to the invention of the electron microscope, Helmut Ruska, a German doctor, was able for the first time to describe both round and "sperm-shaped" particles from a phage suspension adhered to a bacterial membrane. Various stages of bacterial lysis including adsorption, vast bacterial destruction, and development of many newly formed bacteriophages were also described. ${ }^{14,27}$ The findings of some studies showed the usefulness of bacteriophages in the treatment of various infections, including $S$. aureus and 
P. aeruginosa, but due to some limitations of these publications, such as lacking control groups and being conducted in a small area, they failed to assure the rest of the world about the effectiveness and safety of this agent. ${ }^{14,28-30}$ In the last two decades, scientists faced the emergence of MDR, XDR, and PDR bacteria and the slow development of new antibiotics refocused on bacteriophages. Recently, encouraging results comes from some well-designed clinical trials, conducted mainly on wound infection in burn patients, ulcers and chronic otitis. The bacteriophages have become such interesting agents that are amongst the weapons for fighting against antibiotic resistance in the US. Use of bacteriophage in recent insightful research, against MDR, XDR, and PDR bacteria, might be relevant to therapies against $S$. aureus, P. aeruginosa, A. baumannii, and infectious diseases. ${ }^{18,31}$

\section{Why Would We Need Phage Therapy?}

In 1943, more than 10 years after its discovery by Alexander Fleming (1928), ${ }^{32}$ penicillin offered a cure for infectious diseases for the first time and became a pioneer in the treatment of infectious diseases. Thereafter, other antimicrobials including widely used antibiotics, such as streptomycin, chloramphenicol, and tetracycline were discovered. Accordingly, the role of antibiotics in the treatment and prevention of infections, especially during World War II was realized. Based on these facts, a world without antibiotics seems unrealistic. Although antibiotics were initially successful, the production of new antibiotics was unable to keep up with the increasing incidence of infections caused by antibiotic- resistant bacteria and growing rate of antibiotic resistance.

However, the production of new antibiotics is no longer cost-effective, because of the development of resistance to antibiotics immediately after their production. ${ }^{33,34}$ So, the available options for treatment of major MDR bacteria, such as Enterococcus faecium, $S$. aureus, $K$. pneumoniae, $A$. baumannii, $P$. aeruginosa, and Enterobacter were so limited that an urgent need for discovery of alternative antibiotics to fight antibiotic-resistant infections was felt. ${ }^{27}$ Using of bacteriophage as a natural and non-conventional antimicrobial agent in this period of progressive spread of MDR, XDR and PDR bacteria with a paucity of new antibiotics presents a new solution. Today it may be possible to successfully use bacteriophages as described in various cases including food safety, agriculture, veterinary applications, detection and control of foodborne pathogens, industry, the therapeutic use of phage, and clinical diagnostic, such as detection and typing of bacteria in human infection. They have special characteristics, such as bactericidal effect, low inherent toxicity, high selectivity, lack of cross-resistance with antibiotic classes as well as self-multiplication in the presence of the bacterial host that distinguish them from conventional antibiotics. ${ }^{18,27,33,35-37}$ Also, unlike broad-spectrum antibiotics, phage spare the commensal microbiota due to their strain-specific activity, which is particularly important for malnourished and immunodeficient people. Eventually, they can be prepared in dry powder formulations that do not require a cold chain. ${ }^{38}$ According to the aforementioned features, it seems that phage therapy provides the greatest hope for infectious diseases compared to antibiotics in the future.

\section{Major Advantages of Phage Therapy}

Phage therapy boasts many advantages over traditional antibiotics (Table 1). Bacteriophages are natural antibiotics that are able to work against Gram-positive and Gram-negative bacteria. ${ }^{39,40}$ Phages can be isolated rapidly, because of their ubiquitous nature and they are abundant in every ecological niche, which reduces their development costs compared to antibiotics. Accordingly, in an environment containing a certain pathogen, there is a high probability for the presence of specific phages for that microorganism. The phages can be isolated from various environments, such as soil, water, sewage effluent, hospital effluent, hot springs, and fecal material, and also humans and animals gastrointestinal tracts. ${ }^{41}$ It is hard to evaluate the side effects and potential impact of phages, but they appear to be relatively free of sideeffects due to daily contact between humans and phages which may explain why no adverse effects have been detected in humans. ${ }^{42}$ The advances in diagnostic tools and technologies during the last decades have introduced phages as an appropriate option for the diagnosis of the bacteria involved in infections. The bacteriophage is widely used in food preservation for extending the shelf life of refrigerated processed foods ready for consumption for example to the surfaces of preserved meats and cheeses. ${ }^{42}$ Phage therapy may have an impact on the inflammatory response to the infection, decrease in mean $\mathrm{C}$ reactive protein values and leukocyte counts, with a similar tendency of erythrocyte sedimentation rate, an effect that can be one of the most promising aspects of phage therapy. ${ }^{43}$ An important characteristic of 
Table I Advantages and Disadvantages of Using Phage Therapy in the Treatment of Bacteria

\begin{tabular}{|c|c|}
\hline Advantage & Disadvantage \\
\hline $\begin{array}{l}\text { - Active against gram-positive and gram-negative } \\
\text { - Rapid isolation and lower development costs } \\
\text { - Relatively free of side-effects } \\
\text { - Widely used in food preservation } \\
\text { - Disrupt bacterial biofilms, MDR, and XDR } \\
\text { - Phage therapy can affect the immune system with functions such } \\
\text { as decrease in mean C reactive protein values and leukocyte } \\
\text { - Reduces the damage caused to the normal microbial community } \\
\text { - Avoids the potential overgrowth of the secondary pathogen } \\
\text { - Rapidly distribute throughout the body } \\
\text { - Absence of cross-resistance to antibiotics } \\
\text { - Recognizing different cell surface receptors } \\
\text { - Cocktail of phages has some advantages, such as the higher impact } \\
\text { on targeted bacteria }\end{array}$ & $\begin{array}{l}\text { - Bacteria are able to develop resistance against phages } \\
\text { - When the target organism is not present the phages will not replicate } \\
\text { - Phages may carry antibiotic-resistance genes or bacterial virulence } \\
\text { factors } \\
\text { - Phages are perceived by the immune system as invaders and can be } \\
\text { rapidly removed } \\
\text { - There are no clear official guidelines } \\
\text { - Phage rapidly can lyse bacteria that may lead to the release of endo- } \\
\text { toxins and super antigens and induce an inflammatory cascade leading } \\
\text { - to multiple organ failure } \\
\text { - The genome of the majority of phages has been unraveled and the } \\
\text { - It is difficult to extrapolate from in vitro phage growth data to in vivo } \\
\text { prospect } \\
\text { - The phage specificity for bacterial host causing needs to exact host } \\
\text { bacterium be identified } \\
\text { - lytic phages should be used exclusively } \\
\text { Diagnosing an infectious agent in clinical microbiology laboratories is } \\
\text { very time-consuming for using specific bacteriophage solution for } \\
\text { patient } \\
\text { - Phage treatment is not covered by public health insurance }\end{array}$ \\
\hline
\end{tabular}

phages is their high host specificity, which is usually at the species or strain level. This characteristic reduces the damage to the normal microbial community, in contrast to antibiotics that reduce normal flora and consequently can lead to super-infection and other complications. ${ }^{44}$ The concentration of phages increases at the site of infection, because of their innate self-replicating property. So, the presence and persistence of phages avoid the potential overgrowth of the secondary pathogen which, in turn, lowers the need for multiple doses to cure infectious diseases and eventually enhances the efficacy of treatment. In addition, the fast distribution of phages all over the body makes them available to the organs (such as prostate gland, bones, and brain) that are not readily accessible by drugs and their replication in the presence of their hosts enables them to treat infections that otherwise evade treatment. Another advantage of phages is the absence of cross-resistance to antibiotics and mechanisms developed by bacteria to resist antibiotics that prevent interference with phage efficacy, therefore phages are considered as an effective solution against MDR, XDR, and PDR bacteria. ${ }^{18,27,45}$ When a bacterium develops resistance to a particular phage, it will remain sensitive to phages with different cell surface receptors, such as receptors specific to lipopolysaccharides, proteins, teichoic acids. ${ }^{46}$ So, using a cocktail of phages has some advantages such as the higher impact on targeted bacteria and a lower probability of development of phage-resistant bacteria due to the presence of different types of phages infecting the same species and strains. ${ }^{44}$

\section{How Phages Lyse Bacterial Host Cells}

The replication cycle is a prerequisite for the production of bacteriophage particles. If the infected cells release the lytic phage, their bacterial hosts will be lysed. ${ }^{47}$ Accordingly, phages use a single protein called amurins for bacterial lysis, which inhibits peptidoglycan (PG) synthesis or they can use holin-lysin systems. ${ }^{24,47,48}$ The holins cause large pores in the cytoplasmic membrane that provides pathways, through which endolysins release to the cell wall and results in rapid cleavage of several bonds of the PG meshwork and consequently influence the physical integrity of the bacterial cell wall. ${ }^{49,50}$ Based on the difference in the amino acid sequence, holins are divided into class 1,2 , and 3 and $S$. aureus bacteriophage p68 hol15 protein, Lambdoid phage $21 \mathrm{~S}$ protein and phage ACP26F holin fall into these classes, respectively. ${ }^{49-51} \mathrm{On}$ 
the other hand, phage endolysins destroy the cell walls through the hydrolysis of peptidoglycans. Furthermore, endolysins mimic the activities of endopeptidase, amidase, glycosidase or lytic transglycosylase for killing bacterial cells via murein destruction, and they enhance the diffusion of progeny virions at the end of the phage replication cycle. $^{52,53}$ Evidence shows that several phages have the ability to release their endolysins to the extracytoplasmatic medium of the host cells through engaging the host cells' secretion machinery, particularly the general secretion pathway (Sec system), before the viral reproductive cycle is completed. ${ }^{54}$ However, it should be noted that these enzymes are transmitted to the cell wall during phage development, but the host cell lysis does not occur until the end of the lytic cycle. In fact, lysis timing happens when holins, directly or indirectly, abolish the mechanisms that restrain the activity of the secreted endolysins. For example, in some phages, holins can stimulate the host's autolytic activity by their membrane-depolarizing function, and also trigger virion progeny release. ${ }^{55,56}$ To help this process, an antiholin-like protein, has the ability to tune the timing of the holin action in response to environmental cues, while spanins and lipases weaken the outer membrane barrier of Gram-negative hosts bacteria and compromise the mycolyl-arabinogalactan external layer of the mycobacterial cell envelope respectively. ${ }^{55}$ In addition, phages can interfere with the production of various proteins for key host processes, which can ultimately cause them to die. For example, in a study on pseudomonas spp, it was observed that proteins produced by various phages can interfere with the various functions of this bacteria, including cell transcription and translation, RNA degradation, cellular motility, metabolism, clustered regularly interspaced short palindromic repeats (CRISPR)mediated immunity to phages and phage DNA silencing. ${ }^{57}$ There are some studies on how phages lyse bacterial host cells, yet there is a need for a better understanding of their mechanisms in order to use phages to eliminate multi-drug -resistant bacteria, as alternatives to the antibiotics (Figure 1).

\section{Delivery Routes for Phage Therapy in Animal Models}

Bacteriophages can be delivered through different routes; including gastrointestinal, parenteral, topical, and inhalation. Lytic bacteriophages have also been considered for fighting MDR and XDR bacteria as well as biofilm formation on indwelling medical devices. ${ }^{38,58-60}$ Animal studies have confirmed that parenteral delivery, in which the phages are immediately diffused into the systemic circulation, is one of the most general and prosperous delivery methods for bacteriophages therapy. Therefore, recent reports have highlighted

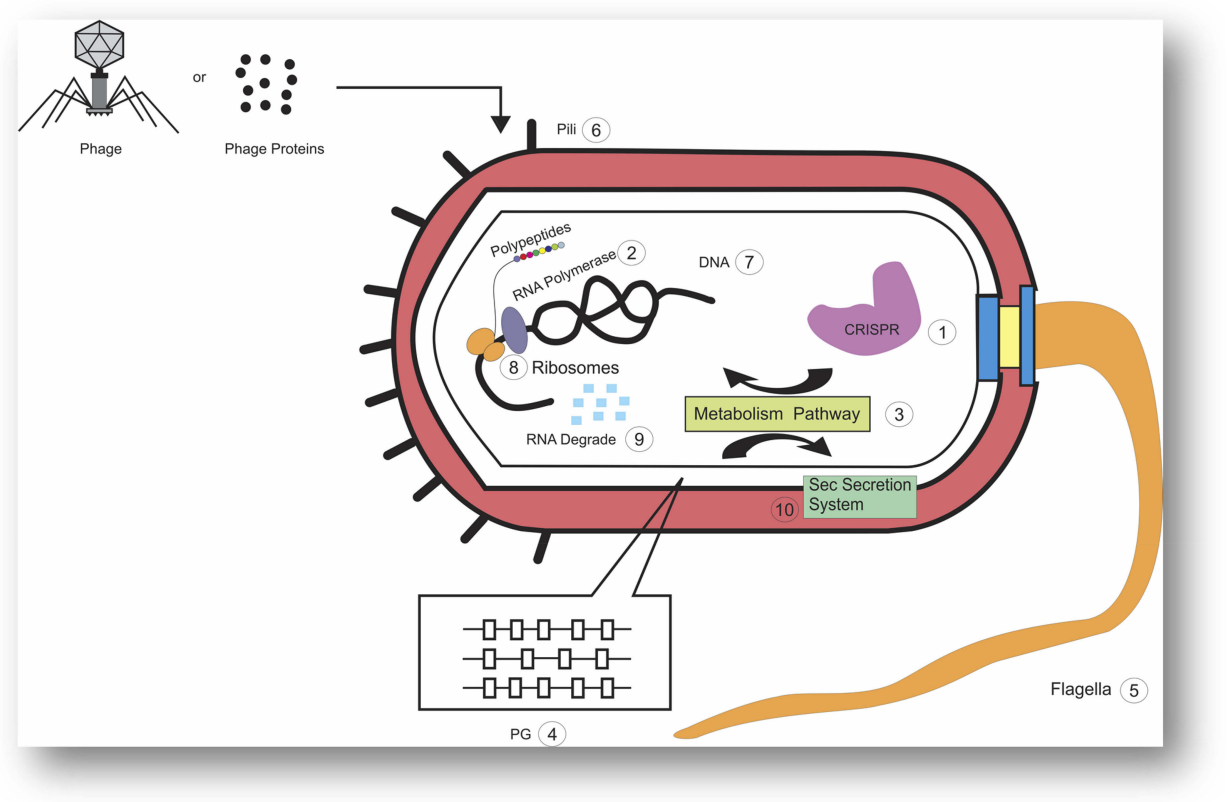

Figure I A schematic representation of a bacterial cell, with the different cellular processes that are influenced by phage or phage proteins. I; CRISPR 2; RNA Polymerase 3; Metabolism Pathway 4; Peptidoglycan 5; Flagella 6; pili 7; DNA 8; Ribosomes 9; RNA degrade 10; Sec Secretion System. 
that the specific sites of administration, such as intramuscular, subcutaneous or intraperitoneal (IP) administrations have a significant effect on the success of phage therapy. To develop and experiment a customized therapeutic phage for treatment of an MDR A. baumannii wound infection, a cocktail containing five members of wild phages was used by Regeimbal et al Phage treatments was followed by IP and topical administration of $4 \times 10^{9}$ PFU of phages preparations and $5 \times 10^{9}$ PFU of phages in PBS topically under the Tegaderm dressing, on top of the wound. When wound therapy performed, it was confirmed that the significance of anticipating population changed during phage therapy and designing intelligent cocktails controlled emergent strains, so wounds began to heal and wound size decreased after day $13 .{ }^{61}$ In a similar study conducted by Vieira et al, a skin infection was induced in mice by IP injection of MDR P. aeruginosa. This study indicates that the phage PA709 can significantly inactivate MDR $P$. aeruginosa in its topical application. For some reasons, such as good performance in the inactivation of MDR $P$. aeruginosa and its effectiveness on a remarkable range of hosts, phage therapy is suggested as a very promising approach for the treatment of $P$. aeruginosa skin infections. ${ }^{60}$ The use of lytic enzymes of phage against antibiotic-resistant Streptococcus pneumoniae infection in a murine sepsis model was tested by Jado et al as a new therapy. The results of this study demonstrated that a single IP injection was sufficient for the effective protection of the mice. Regarding the bacteremia, they found that the mean colony count in lysin-protected animals was $<10^{6}$ colony forming unit (CFU)/mL and it reduced gradually over time to an undetectable level while in unprotected mice the colony counts reached $>10^{7} \mathrm{CFU} / \mathrm{mL}^{62}$ Furthermore, bacteriophage therapy was examined in the clinical isolates of vancomycinresistant E. faecium by IP injection of $10^{9} \mathrm{CFU}$, which rescued mice by inducing bacteremia. Although the fatal effect of bacteremia appeared within 48h, a single IP injection of 3 $\times 10^{8}$ plaque-forming unit (PFU) of the phage strain was sufficient to rescue $100 \%$ of the animals. Even in animals that were moribund, because of delayed treatment, a single injection of this phage preparation could rescue nearly $50 \%$ of them. ${ }^{63}$ The rescue of septicemic mice infected by MDR $P$. aeruginosa using lytic bacteriophages was evaluated by Vinodkumar et al IP injection of $10^{7} \mathrm{CFU}$ of MDR $P$. aeruginosa was applied for inducing septicemia in mice. In this study, a phage strain with the lytic activity against many types of clinical isolates of MDR $P$. aeruginosa was used. A single IP injection of $3 \times 10^{9}$ PFU of the phage strain was adequate for saving all of the animals. ${ }^{64}$ In another study, the effect of phage therapy on antibiotic resistant Mycobacterium avium infection was evaluated in vivo. M. avium was used to create an infection and 7 days later, the infected mice were treated once or twice with TM4 phage $\left(7.9 \times 10^{10} \mathrm{PFU} / \mathrm{mL}\right)$ intravenously. After treatment, the number of M. avium in the spleen decreased significantly under the effect of TM4 phage, however, $23 \%$ of recovered bacteria from treated mice developed resistance to TM4. ${ }^{65}$ The effect of $1.0 \mathrm{mg}$ bacteriophage lysin administered by IP injection on controlling MDR A. baumannii sepsis, and biofilm formation on catheters and the joint was examined in mice. A marked decline in total biofilm biomass on the catheters was observed, which was confirmed using scanning electron microscopy. Moreover, the survival rate of the mice infected with this highly lethal dose of $A$. baumannii in their systemic circulation increased up to $50 \%$ after the treatment. ${ }^{39}$ Bacteriophages were also used to protect mice against a lethal XDR $A$. baumannii infection in a study described by Deng et al Mice in the sepsis control group, antibiotics treatment group, and phage treatment group were injected with $1 \mathrm{~mL}$ XDR $A$. baumannii. A slightly higher survival ratio of mice was observed in the phage treatment group compared with the antibiotics treatment group. ${ }^{66}$ Morello et al used an MDR $P$. aeruginosa mucoid strain isolated from a cystic fibrosis patient to develop a mouse lung-infection model. The intranasal route was selected to deliver bacteria and bacteriophages to the immunocompetent mice. To investigate bacteriophage P3-CHA effects, a fourday preventive treatment protocol was used in which one single dose rescued $100 \%$ of infected mice. ${ }^{67}$ Based on the above reports, phage therapy should be considered as a viable alternative for the treatment of bacterial infections in the future due to its specificity and lack of side effects.

\section{Phage Therapy in Humans}

In recent years, phages have been used to treat various infections caused by bacteria such as $S$. aureus, $P$. aeruginosa, A. baumannii and E. faecalis. Phage therapy in these studies has usually been applied following treatment failures with antibiotics and good results have been obtained with phages. In a study performed on a 68-year-old diabetic patient with necrotizing pancreatitis complicated by an MDR A. baumannii infection, it was reported that 9 different lytic phages were used because of the resistance of $A$. baumannii isolated from this patient to different antibiotics. These phages were administered percutaneously and intravenously into the abscess, which cleared the infection and 
improved the patient's condition. ${ }^{68}$ Ooi et al used phage cocktail AB-SA01 to treat chronic rhinosinusitis caused by the MDR $S$. aureus. The administration of multiple intranasal doses of phage resulted in a successful treatment without any adverse effects which implied that this treatment could be an alternative to antibiotics. ${ }^{69}$ In another study, staphylococcal phage $\mathrm{Sb}-1$ was used for the treatment of ulcers in diabetic patients, and the results showed that the topical use of a staph mono-phage preparation could improve the infection even if the antibiotic treatment had failed. ${ }^{70}$ Furthermore, bacteriophage OMKO1 was used by Chan et al for the treatment of an aortic graft infected by $P$. aeruginosa, since antibiotic treatment is usually not practical in this situation. Their results showed that phage and ceftazidime improved the infection and there were no signs of recurrence. In this study, they directly reached the Perigraft collection in front of the aortic root by needle puncture using image guidance. ${ }^{71}$ Another case study demonstrated that intravenous bacteriophage cocktail BFC1 monotherapy can be used to treat $P$. aeruginosa septicaemia in humans. ${ }^{72}$ Finally, in another study, phage was used to treat prostatitis caused by E. faecalis, in which the rectal application of phage lysates was used to access tissue and inject phages. The results showed the elimination of the infection, the improvement of the patients' conditions and the lack of early disease recurrence. It should be noted that the use of antibiotics, autovaccines, and laser Biostimulation for the treatment of the patients also failed. ${ }^{73}$ It needs to be pointed out that other studies investigating the therapeutic effects of phages on infections have reported no adverse effects for different phages. ${ }^{74,75}$ Therefore, due to the high inhibition of different antibiotic-resistant bacteria and minor side effects, phages can be suggested as a potential replacement for antibiotic treatments.

\section{Global Concern for MDR, XDR and PDR Pathogens}

Antimicrobial resistance is a growing global concern, and the resistance of bacteria to conventional antibiotics leads to 10 million deaths each year. The widespread and incorrect use of antibiotics over time has created various resistance mechanisms in bacteria that lead to MDR. ${ }^{76}$ MDR organisms are labeled as such, because of their in vitro resistance to more than one antibiotic or a key antimicrobial agent. ${ }^{77,78}$
Also, a definition of MDR is described as the resistance to three or more antimicrobial classes, but currently there is not any consensus on a standard definition for MDR by the medical community. ${ }^{79,80}$ Bacteria that are categorized as XDR or extensive drug resistance, are those that are resistant to all or nearly all approved antimicrobial agents. ${ }^{78,81}$ PDR is a term that refers to bacterial isolates with resistance to all approved effective antibiotics for empirical treatments. ${ }^{82,83}$ Antibiotic resistance in Gram-negative bacteria is higher due to the presence of outer membranes and defense agents, such as the efflux pumps compared to Gram-positive bacteria. Therefore, finding an effective strategy to control antibiotic resistance, prevent its spread and develop new antibiotics against Gram-negative bacteria is more difficult than against Gram-positive ones. ${ }^{84,85}$ Different studies in recent years have shown that Gram-positive and Gram-negative bacteria, such as vancomycin-resistant enterococci, methicillinresistant $S$. aureus (MRSA), Enterobacteriaceae with extended-spectrum b-lactamase and XDR A. baumannii and $P$. aeruginosa have caused the highest mortality among infected patients. ${ }^{86,87}$ On the other hand, it should be noted that of extensively drug-resistant tuberculosis (XDR-TB), MDR Clostridium difficile and newly identified transmissible carbapenamase, New Delhi metallo-betalactamases (NDM) in Enterobacteriaceae are expanding all over the world, especially in developing countries, and may become a big problem in the coming years. ${ }^{3,88,89}$ Intrinsic properties, such as external barriers, which prevent the entry of drugs into bacteria, natural mutations in antibiotic targets and acquired features, such as sequestration of the drug, efflux pumps and enzyme-dependent drug alterations cause such high levels of resistance to existing antibiotics. ${ }^{11}$ Genetic transmission of resistance agents by plasmids, integrons, transposons, and other mobile genetic elements, in addition to widespread antibiotic resistance, also transforms commensal bacteria into pathogens. ${ }^{90}$ Infection with bacteria with high levels of resistance increases hospitalization time, delays the treatment process, requires the use of more toxic antibiotics, raises therapeutic costs, and brings many other problems for patients. $^{91,92}$ In 2005 almost 19,000 patients died in the United States from MRSA infection, which is even higher than annual deaths due to AIDS. ${ }^{93}$ So, there is an obvious and essential medical need for a new approach for treating infections caused by MDR, XDR and PDR pathogens. The use of antibiotic combinations and the development of new antibiotics are the current strategies for the treatment of MDR bacterial infections, however, the poor success rate has dampened interest. So, non-antibiotic remedies to cure bacterial 
infections are now under serious consideration and using a specific phage that targets bacterial pathogen is suggested as a preferable, potential choice for substitution to other failed treatments. ${ }^{13,94}$

\section{Bacteriophage for the Treatment of MDR, XDR, and PDR Bacteria}

Recent investigations using in vivo and in vitro conditions have introduced the phages as a new treatment against a range of clinically significant pathogens. When challenges occurred with MDR $S$. aureus, the bacteriophage $\phi \mathrm{MR} 11$ lysed cells of a number of $S$. aureus in a fast and complete manner in the growing condition, and also, effectively eradicated MRSA that had been artificially inoculated into the nares of mice. ${ }^{95}$ Three phages including SL1, SL2, and SL4 with the lytic activity that were collected from hospital sewage were applied against clinical isolates of MDR $P$. aeruginosa. To rescue planktonic cells of MDR $P$. aeruginosa strains, a single phage strain of that three selected ones was adequate. The SL2 was the most potent in suppressing planktonic cultures, however, the greatest anti-biofilm activity was observed with SL4 in vitro condition. No synergistic and no antagonistic effects of a cocktail was found with the three phages, however, the three-phage cocktail was as effective as the best phage alone. ${ }^{96}$ Various studies demonstrated that different bacteriophages were able to reduce and lyse MDR $P$. aeruginosa in animal and in vitro conditions. ${ }^{64,97,98}$ Additional animal studies show similarly promising results for MDR E. coli O25:H4-ST13, Vibrio parahaemolyticus, and S. aureus. ${ }^{99-101}$ There is even an indication that the phages containing WP1, WP2, WP3, WP4, and WP5 are capable of lysing antibiotic-resistant bacteria, as in the case of MDR and XDR P. aeruginosa. ${ }^{102}$ After an in vitro investigation, it was realized that phage $\phi \mathrm{km} 18 \mathrm{p}$ is able to effectively lyse the most XDR A. baumannii and also using of phages as a cocktail has the potential of lysing XDR $A$. baumannii isolates of all various genotypes. $^{45}$ The effect of $\phi \mathrm{KMV}, \phi \mathrm{PA} 2, \phi \mathrm{Paer} 4$, and $\phi$ E2005 phages on 11 strains of MDR, and 1 strain of XDR were tested by Abigail and et al. The results demonstrated that phages were able to lyse MDR $P$. aeruginosa and prevent biofilm formation, however, no effect on XDR $P$. aeruginosa lysis was detected. ${ }^{17}$ A study that investigated the effect of phages on widely drug-resistant $A$. baumannii in an animal model demonstrated that the survival ratio of mice with systemic infection increased more in the phage treatment group than that of the antibiotics treatment group.
Furthermore, the inflammation responses were significantly controlled by phages, and they effectively cleaned bacteria in lung, liver, spleen, and kidney in mice with XDR A. baumannii. $^{66}$ The isolated bacteriophage vB_AbaMIME-AB2 was able to adsorb its host cells, and among the 22 clinical strains of MDR A. baumannii, only three strains were affected and lysed by the phage. ${ }^{103}$ Effects of three lytic phages, individually or combined in a cocktail, against XDR and MDR $P$. aeruginosa suggested that they were highly susceptible to at least one phage, as well as to the cocktail, and there was a relation between genotype and the susceptibility pattern. ${ }^{104}$ In another study, which was performed by Lood et al, phage lysin was found to be capable of killing the MDR A. baumannii clinical isolates in a mouse sepsis model. Also, PlyF307 remarkably reduced the planktonic and biofilm $A$. baumannii both in vitro and in vivo, which finally rescued mice from lethal $A$. baumannii bacteremia. ${ }^{39}$ Phage therapy was performed among 96 isolates of $P$. aeruginosa composed of 2 non-MDR (2.1\%), 94 MDR (97.9\%), 63 XDR $(65.6 \%)$, and 1 PDR (1.1\%) isolates. The use of cocktails of phages showed that they had activity against an extended host range including all MDR, XDR, and PDR strains. ${ }^{105}$ The use of phage Abp1 against human cells and mice infected by PDR A. baumannii demonstrated that Abp1 can rescue HeLa cells from $A$. baumannii infection. In A. baumannii infection in mice, Abp1 therapy, either local or systemic, displays good therapeutic effects. ${ }^{18}$ Myoviridae bacteriophage vB_AbaM_IME200 against PDR A. baumannii was tested by Bai et al. The results demonstrated that phage and its depolymerase had strong lytic activity against PDR A. baumannii. ${ }^{106}$ Furthermore, the combined use of phages and antibiotics has shown better effects than antibiotic therapy alone, against biofilm and drug resistant bacteria such as Burkholderia cepacia, P. aeruginosa, E. coli, Klebsiella pneumoniae, E. faecalis, A. baumannii, $S$. pneumoniae, and $S$. aureus in multiple studies. ${ }^{15,16,107-116}$ Some of phage therapy studies are summarized in Table 2.

\section{Phage Resistance in Bacteria}

Although phages are typically effective against antibioticresistant bacteria, bacteria have acquired a significantly wide array of sophisticated defense strategies to survive phage infections (Table 3). Accordingly, the modes of action of resistance to phages differs from those to antibiotics; nevertheless, several reports demonstrated that MDR, XDR, and PDR bacteria are resistant to bacteriophages. ${ }^{45,117,118}$ These mechanisms include endonucleases widely used as a part of restriction-modification (R-M) systems, which can cleave 
Table 2 Summary of Major Experimental Studies with Phage Therapy

\begin{tabular}{|c|c|c|c|c|c|c|}
\hline $\begin{array}{l}\text { Name and } \\
\text { Reference }\end{array}$ & $\begin{array}{l}\text { Published } \\
\text { Time }\end{array}$ & Country & Subjects & $\begin{array}{l}\text { Type of Phage } \\
\text { for Treatment }\end{array}$ & $\begin{array}{l}\text { Type of } \\
\text { Resistance } \\
\text { Bacteria }\end{array}$ & Outcomes \\
\hline Rashel et $\mathrm{al}^{95}$ & 2007 & Japan & Mice & $\phi M R I I$ & MDR S. aureus & $\begin{array}{l}\text { Effectively eradicated MRSA into the nares } \\
\text { of mice }\end{array}$ \\
\hline Latz et $\mathrm{al}^{96}$ & 2017 & Germany & In vitro & SLI, SL2, and SL4 & MDR $P$. aeruginosa & $\begin{array}{l}\text { Greatest anti-biofilm and planktonic cells } \\
\text { activity was observed }\end{array}$ \\
\hline Golkar et $\mathrm{al}^{97}$ & 2013 & USA & Mice & PS5 & MDR $P$. aeruginosa & $\begin{array}{l}\text { Deep wound infection and chronic infection } \\
\text { treated the each of the infections by } \\
\text { respective dermal application of phages }\end{array}$ \\
\hline Wang et $\mathrm{a}^{98}$ & 2006 & China & Mice & $\varnothing A 392$ & $\begin{array}{l}\text { Imipenem- } \\
\text { resistant } \\
\text { P. aeruginosa }\end{array}$ & $\begin{array}{l}\text { Protection from death occurred only in } \\
\text { animals inoculated with bacteria-specific } \\
\text { virulent phage strains }\end{array}$ \\
\hline Pouillot et al ${ }^{100}$ & 2012 & France & Rat & $\mathrm{EC} 200^{\mathrm{PP}}$ & $\begin{array}{l}\text { MDR E. coli O25: } \\
\text { H4-STI3I }\end{array}$ & $\begin{array}{l}\text { In the sepsis model and meningitis model } \\
\text { phage rescued animals }\end{array}$ \\
\hline Jun et $\mathrm{al}^{99}$ & 2014 & Korea & Mice & $p \vee p-I$ & $\begin{array}{l}\text { MDR } \\
\text { V. parahaemolyticus }\end{array}$ & $\begin{array}{l}\text { Phage-treated mice displayed protection } \\
\text { from a } V \text {. parahaemolyticus infection and } \\
\text { survived lethal oral and intraperitoneal } \\
\text { bacterial challenges }\end{array}$ \\
\hline Wills et al ${ }^{101}$ & 2005 & $\begin{array}{l}\text { United } \\
\text { Kingdom }\end{array}$ & Rabbit & LS2a & $\begin{array}{l}\text { Drug-resistant } \\
\text { S. aureus }\end{array}$ & $\begin{array}{l}\text { Phage prevented abscess formation in } \\
\text { rabbits when it was injected simultaneously } \\
\text { with S. aureus }\end{array}$ \\
\hline $\begin{array}{l}\text { Kwiatek } \\
\text { et al }\end{array}$ & 2015 & Poland & In vitro & $\begin{array}{l}\text { WPI, WP2, WP3, } \\
\text { WP4, and WP5 }\end{array}$ & $\begin{array}{l}\text { MDR and XDR } \\
P \text {. aeruginosa }\end{array}$ & $\begin{array}{l}\text { Bacteriophages WP3, WP2 and WP5 } \\
\text { exhibited the highest lytic activity against } \\
\text { P. aeruginosa strains }\end{array}$ \\
\hline Shen et $\mathrm{al}^{45}$ & 2012 & Taiwan & $\begin{array}{l}\text { In vitro } \\
\text { and } \\
\text { human } \\
\text { cells } \\
\text { culture }\end{array}$ & $\varphi k m / 8 p$ & XDR A. baumannii & $\begin{array}{l}\text { Phage } \varphi \mathrm{km} / 8 \mathrm{p} \text { improved human lung } \\
\text { epithelial cells survival rates when they } \\
\text { were incubated with } A \text {. baumannii }\end{array}$ \\
\hline Mapes et al ${ }^{17}$ & 2016 & USA & In vitro & $\begin{array}{l}\phi \mathrm{KMV}, \phi \mathrm{PA} 2, \\
\phi \mathrm{Paer} 4, \text { and } \\
\phi \mathrm{E} 2005\end{array}$ & $\begin{array}{l}\text { MDR and XDR } \\
P \text {. aeruginosa }\end{array}$ & $\begin{array}{l}\text { Phages were able to lyse MDR } P \text {. aeruginosa } \\
\text { and prevent biofilm formation }\end{array}$ \\
\hline Larché et al ${ }^{104}$ & 2012 & France & In vitro & $\mathrm{FrNa} 3$ and $\mathrm{FrNa9}$ & $\begin{array}{l}\mathrm{XDR} \text { and } \mathrm{MDR} \\
P . \text { aeruginosa }\end{array}$ & $\begin{array}{l}\text { Bacteriophages were found to lyse } 42 \text { of the } \\
44 \text { analyzed strains }\end{array}$ \\
\hline Shokri et al ${ }^{105}$ & 2017 & Iran & In vitro & Psul and Psu2 & $\begin{array}{l}\text { MDR, } X D R \text {, and } \\
\text { PDR P. aeruginosa }\end{array}$ & $\begin{array}{l}\text { Cocktails of phages had extended host } \\
\text { range activity against all MDR, XDR, and } \\
\text { PDR strains }\end{array}$ \\
\hline Yin et $a^{18}$ & 2017 & China & $\begin{array}{l}\text { Mice and } \\
\text { human } \\
\text { cells } \\
\text { culture }\end{array}$ & Abpl & PDR A. baumannii & $\begin{array}{l}\text { Abpl can rescue HeLa cells from } \\
\text { A. baumannii infection }\end{array}$ \\
\hline Bai et al ${ }^{106}$ & 2018 & China & In vitro & vB_AbaM_IME200 & PDR A. bsaumannii & $\begin{array}{l}\text { Phage had strong lytic activity against PDR } \\
\text { A. baumannii }\end{array}$ \\
\hline Wright et $\mathrm{al}^{75}$ & 2009 & UK & Human & Biophage-PA & $\begin{array}{l}\text { Antibiotic } \\
\text { resistant } \\
\text { P. aeruginosa in } \\
\text { chronic } \\
\text { otitis }\end{array}$ & $\begin{array}{l}\text { P. aeruginosa counts were significantly lower } \\
\text { only in the phage treated group and clinical } \\
\text { indicators improved for the phage treated } \\
\text { group relative to the placebo group. }\end{array}$ \\
\hline
\end{tabular}

(Continued) 
Table 2 (Continued).

\begin{tabular}{|c|c|c|c|c|c|c|}
\hline $\begin{array}{l}\text { Name and } \\
\text { Reference }\end{array}$ & $\begin{array}{l}\text { Published } \\
\text { Time }\end{array}$ & Country & Subjects & $\begin{array}{l}\text { Type of Phage } \\
\text { for Treatment }\end{array}$ & $\begin{array}{l}\text { Type of } \\
\text { Resistance } \\
\text { Bacteria }\end{array}$ & Outcomes \\
\hline Rhoads et $\mathrm{al}^{74}$ & 2009 & USA & Human & WPP-20I & $\begin{array}{l}\text { Three common } \\
\text { bacterial wound } \\
\text { pathogens } \\
\text { including } S \text {. } \\
\text { aureus, } \\
\text { P. aeruginosa and } \\
\text { E. coli }\end{array}$ & $\begin{array}{l}\text { No significant difference }(\mathrm{p}>0.05) \text { was } \\
\text { determined between the test and control } \\
\text { groups for frequency of adverse events, rate } \\
\text { of healing, or frequency of healing. }\end{array}$ \\
\hline Jennes et $\mathrm{al}^{72}$ & 2017 & Belgium & Human & $\mathrm{BFCl}$ & $\begin{array}{l}\text { MDR } P . \text { aeruginosa } \\
\text { septicaemia }\end{array}$ & $\begin{array}{l}\text { Not only blood cultures turned negative, } \\
\text { CRP levels dropped and the fever } \\
\text { disappeared but also kidney function } \\
\text { recovered after a few day. }\end{array}$ \\
\hline Chan et $\mathrm{al}^{71}$ & 2018 & USA & Human & OMKOI & $\begin{array}{l}\text { Drug-resistant } \\
\text { P. aeruginosa }\end{array}$ & $\begin{array}{l}\text { A single application of phage OMKOI and } \\
\text { ceftazidime, the infection appeared to } \\
\text { resolve with no signs of recurrence. }\end{array}$ \\
\hline $\begin{array}{l}\text { Schooley } \\
\text { et } \mathrm{al}^{68}\end{array}$ & 2017 & USA & Human & $\begin{array}{l}\text { AB-Navyl, AB- } \\
\text { Navy4, AB- } \\
\text { Navy7I, AB- } \\
\text { Navy97, } \\
\text { AbTP3ФI, } \\
\text { AC4, CIPI2, } \\
\text { C2P2I, C2P24 }\end{array}$ & $\begin{array}{l}\text { MDR A. baumannii } \\
\text { infection }\end{array}$ & $\begin{array}{l}\text { This clinical study showed that systemic } \\
\text { administration of the bacteriophage therapy } \\
\text { through intravenous administration was } \\
\text { cured A. baumannii infection in anatomic } \\
\text { sites. }\end{array}$ \\
\hline Ooi et $\mathrm{al}^{69}$ & 2019 & Australia & Human & AB-SAOI & $\begin{array}{l}\text { MDR S. aureus } \\
\text { infections }\end{array}$ & $\begin{array}{l}\text { Results showed that treatment was well } \\
\text { performed, no adverse effects were } \\
\text { observed }\end{array}$ \\
\hline Letkiewic $^{73}$ & 2009 & Poland & Human & PT & $\begin{array}{l}\text { Chronic E. faecalis } \\
\text { Prostatitis }\end{array}$ & $\begin{array}{l}\text { Phage eliminated infection, and improved } \\
\text { patients with lack of early disease } \\
\text { recurrence. }\end{array}$ \\
\hline
\end{tabular}

phage DNA. Development of adaptive immunity by interfering CRISPR sequences has results in degradation of the injected phage DNA. ${ }^{117,119}$ There is clear evidence that genetic mutations decrease bacterial virulence and spoil or modify the molecules that the phage uses as receptors, since bacterial receptors for phage adsorption are often virulent determinants or crucial molecules to the bacterial cell. In some instances, phage receptors may have phase variation or hide behind a physical barrier, such as a capsule or other extracellular polymer. These structures can elevate bacterial survival in various conditions by protecting the bacteria against harsh ecological niches and, sometimes, hindering phages to find their receptors by providing a physical obstacle between them. ${ }^{120,121}$ On the other hand, a minimum population of bacteria that produces the receptor slowly and at low levels determines the long period sustainability and phage-resistant mutants can be efficiently isolated. ${ }^{122}$
Bacillus species were shown to exhibit antiviral effects when producing RNase III and MazF and action of RNases is more remarkable under starvation. Another agent with anti-phage activity is secreted RNase of Bacillus with the ability of interference with phage adsorption or causing abortive infection. ${ }^{123}$ Super infection exclusion (Sie) systems are proteins that prevent the phage DNA to enter into the bacterial cytoplasm. These proteins are anchored to the membrane or associated with its components. Sie systems are associated with the prophages that are found in various bacteria and the bacteria carrying lysogenic phage can prevent subsequent infection by other phages. However, only a few of these systems characterized in Gram-negative and Gram-positive bacteria were reported. ${ }^{118,120}$ Bacteriophage exclusion (BREX) is another new system of bacterial defense in which the DNA methylation of the host cell blocks phage DNA replication. BREX defense systems are six-gene 
Table 3 A Summary of the Anti-Phage Mechanisms of Bacteria

\begin{tabular}{|c|c|}
\hline $\begin{array}{l}\text { Anti-Phage } \\
\text { Mechanism }\end{array}$ & Mode of Action \\
\hline $\begin{array}{l}\text { Restriction-modification } \\
\text { (R-M) }\end{array}$ & Cleaving phage DNA \\
\hline CRISPR & Degradation of the injected phage DNA \\
\hline Genetic mutation & $\begin{array}{l}\text { Disturbance in receptors for phage } \\
\text { adsorption }\end{array}$ \\
\hline RNases & Interfere with phage adsorption \\
\hline $\begin{array}{l}\text { Super infection exclusion } \\
\text { (Sie) systems }\end{array}$ & $\begin{array}{l}\text { Prevent the entry of phage DNA into } \\
\text { bacterial cytoplasm }\end{array}$ \\
\hline BREX defense system & Block phage DNA replication \\
\hline Quorum sensing defense & $\begin{array}{l}\text { Alternate between different phage } \\
\text { protection mechanisms depending on } \\
\text { population cell density }\end{array}$ \\
\hline $\begin{array}{l}\text { Abortive infection (Abi) } \\
\text { systems }\end{array}$ & $\begin{array}{l}\text { Blocking phage multiplication and cause } \\
\text { premature bacterial cell death upon } \\
\text { phage infection }\end{array}$ \\
\hline DISARM & Restricts incoming phage DNA \\
\hline $\begin{array}{l}\text { Phage-inducible } \\
\text { chromosomal islands } \\
\text { (PICls) }\end{array}$ & $\begin{array}{l}\text { Interfere with the reproduction of } \\
\text { phages }\end{array}$ \\
\hline $\mathrm{PICl}$-like element & The activity is not yet known \\
\hline
\end{tabular}

cassettes in Bacillus cereus, which undergo extensive horizontal gene transfer and provide complete phage resistance to a wide variety of phages, containing lytic and temperate ones. ${ }^{124}$ Quorum-sensing regulation as a defense mechanism in pathogens allows shifting between various phage protection mechanisms based on population cell density. Under high-cell-density conditions, quorum sensing mediated down-regulation of phage receptor adsorption and bacteria unsusceptible to phage infection, but when the density of cells was low, quorum sensing did not affect the phage receptor expression and the cells were quite susceptible to phage. ${ }^{125,126}$ DISARM (defense island system associated with restriction-modification), widely spread in bacteria and archaea, is a new type of anti-phage mechanism that restricts incoming phage DNA and thereby confront viruses of various families of tailed phages. DISARM is a system made up of five genes, one for DNA methylation and four other genes annotated as a helicase domain, a phospholipase D domain, a DUF1998 domain and a gene of unknown function. ${ }^{127}$ Abortive infection (Abi) systems are mechanisms of innate immunity in bacteria that limit phage dissemination by blocking phage multiplication and cause premature bacterial cell death upon phage infection. Accordingly, the goal of this "altruistic suicide" strategy is killing the infected cells and decreasing the phage population at minimum meanwhile protecting the uninfected surrounding cells. ${ }^{128}$ Also, some bacterial chromosomal and plasmid toxinantitoxin (TA) systems are subgroups of Abi systems that play a role in phage defense. ${ }^{129,130}$ The phage-inducible chromosomal islands (PICIs) of Gram-positive bacteria are genetic elements with high mobility and substantial contribution to horizontal gene transfer, host adaptation, virulence, and phage parasites. These mobile genetic elements have the capacity to interfere with the reproduction of certain phages. They were initially identified in $S$. aureus, but now these elements are thought to occur widely in Gram-positive bacteria such as Lactococci, Pneumococci, E. faecalis, and Streptococci. ${ }^{131,132}$ A PICI-like element with the ability to inhibit a virulent phage has also been detected recently. Although the basis of its mechanism of action is still unknown, it is certain that such elements are very common among the Lactococci, $V$. cholera, and Streptococci. ${ }^{131,133}$

\section{How Phages Overcome Bacterial Bacteriophage Resistance}

The combat for survival between bacteria and the phages that infect them has led to the evolution of multiple bacterial defense systems and phage-encoded antagonists of these systems. In contrast to the various known anti-phage systems of bacteria, the counteracting mechanisms of phages are poorly understood. Some reports have pointed to several of these mechanisms that allow phages to evade. ${ }^{133-135}$ Phages with the potential of acquiring new receptors tropism can alter their receptor-binding protein, this means that when a host receptor changes to a mutated form, phages can recognize the modified receptor structure and in this way they counteract disturbance in receptors for phage adsorption. When a surface component like a capsule or another exopolysaccharide (EPS) compound conceal bacterial receptors, phages can increase binding to the receptor by hydrolyzing these barriers using different enzymes such as endosialidase, hyaluronanlyase, exopolysaccharide degrading enzyme, and alginase. When the host receptors are expressed only under particular environmental conditions, phase are variable or expressed only during a certain growth phase, encoding receptor-binding proteins with variable specificities enables phages to increase the chance of infecting their host. Accordingly, encoding multiple receptor-binding proteins with varying specificity leads to an expansion of host range. ${ }^{48,136,137}$ To escape the notable variety of R-M systems, phages utilize types of antirestriction strategies, which can be broadly classified into passive and active 
mechanisms. When a phage DNA enters the host, passive mechanisms protect the phage DNA if the host methyltransferase acts rapidly and modifies the phage DNA before recognition by the endonuclease. Although a modified phage genome can replicate in the host, it is recognized as a foreign phage in other cells, except in the cells that express the same R-M system. Active mechanisms of phage evasion occur when the phage can co-inject proteins with its genome to attach straightly to the phage DNA and mask restriction sites or binds to both the methyltransferase and the endonuclease of $\mathrm{R}-\mathrm{M}$ system and control of its activity. In addition, multiple encoding modification genes with different advantages for example, methylation, have also been demonstrated in phages. These modification genes protect phages from the activity of the host endonuclease and the protection occurs in all hosts. Five distinct anti-CRISPR genes are presented in $P$. aeruginosa temperate phages. These genes encode a small protein, which is delivered to the cell along with the viral genome, or it can immediately neutralize the immune system of the host by interfering with the formation or action of the CRISPR-Cas ribonucleo protein. ${ }^{138}$ The mutation is another anti-CRISPR mechanism that does not significantly impair phage infectivity or fitness. As a result, this mutation is a single-nucleotide substitution event on protospaceradjacent motif also known as the seed sequence for CRISPR. Some phages harbor acr genes, which antagonize bacterial CRISPR-Cas immune systems. Acr is a phageencoded protein that interferes with the CRISPR-Cas system by binding to the components of its machinery. ${ }^{139,140}$ The phage-encoded CRISPR-Cas system is a system used for counteracting a phage inhibitory chromosomal island of the bacterial host. Phages can hijack bacterial CRISPR-Cas systems to promote their own multiplication, which allows the phage to complete its lytic cycle. ${ }^{141}$ Unlike other systems, Abi systems induce death of the host cell, but some phages can bypass the Abi mechanism through mutations in genes involved in nucleotide metabolism. Also, phages can encode a pseudo-antitoxin molecule that functionally substitutes the bacterial antitoxin, consequently neutralizes toxin activity and eludes host death. ${ }^{136}$

\section{Disadvantages of Phage Therapy and the Need for Further Studies}

In spite of several advantages noted yet for bacteriophages, they have some limitations. Phages may be resisted by bacteria. Some of the resistance mechanisms developed by bacteria against phages have already been identified. ${ }^{142}$ Another issue regarding the phage therapy is that the bacteriophages are potentially able to transfer the antibiotic-resistance genes or other bacterial virulence from a bacterium to another, which are carried through generalized transduction. ${ }^{143}$ Although there are standardized methods for the production of phage cocktails, clear official guidelines are not available. The phage immunogenicity is another source of concern, that is, the patient's immune system may recognize the phage as a potential invader and therefore rapidly remove it from the systemic circulation, which may result in a concentration lower than its effective dose. $^{27}$ The genome of the majority of phages has been unraveled, although, the function of many of these genes is still unknown. ${ }^{144}$ At the end of its antibacterial action, lytic phages induce rapid lysis of a large number of bacteria in vivo that may lead to the release of endotoxins and super antigens from Gramnegative bacteria. This release of endotoxins may induce an inflammatory cascade that eventually lead to a multiple organ failure. ${ }^{44}$ In scientific works, extrapolation of findings of in vitro studies to in vivo situations and even generalization of findings from one in vivo situation to another is difficult and they must be interpreted with caution. ${ }^{145}$ Since the phages are hostspecific agents, the exact host bacterium must be identified, because the strain specificity is rather than species specificity, and it can increase difficulty when preparing phages for highly diverse bacterial variants. ${ }^{144}$ Table 1 summarizes different disadvantages of phage therapy. The specificity of the phage against pathogens can be both advantageous and disadvantageous for phage therapy. Because of this characteristic of phages, a bacterial infectious agent must first be isolated and cultured using standard microbiological diagnostic methods and fully identified, then a specific bacteriophage solution is administered to the patient. Accordingly, the process of diagnosing an infectious agent in clinical microbiology laboratories is very time-consuming and has limitations in health care settings. ${ }^{27}$ Furthermore, in the treatment of infectious diseases, lytic phages should be used exclusively because lysogenic phages delay the lysis of bacteria and prevent the effect of phages on acute infections. ${ }^{146}$ On the other hand, phage treatment in most countries except Poland and Switzerland is not covered by public health insurance, which is a major financial problem for patients. ${ }^{147,148}$ At present, phages are not accepted as pharmaceutical drugs, and current 
European pharmacological regulations, definitions and standards are not sufficiently adapted to phage preparations. Therefore, an international nonprofit called P.H.A. G.E (for Phages for Human Application Group Europe) was developed by a Belgian research team and some members of the Pasteur Institute in Paris to create a specific framework for the use of bacteriophages. ${ }^{27}$ In spite of these undesirable properties, applying phages for the treatment of resistant bacteria is still a very good alternative, because their therapeutic effects have been approved in several studies. So, it can be considered as a good treatment option for resistant infections, because it may be the only option available for rescuing patients.

\section{Conclusion and Perspectives}

Infrequency of new antibiotics against MDR, XDR, PDR, and resistant forms of bacteria, such as biofilm, in nosocomial infections renders bacteriophages as potential new tools for treatment. There is an increased demand for bacteriophage-based therapy in such resistant bacteria and phage cocktails are increasingly used against bacteria with phage resistance mechanism. The results of animal studies have been in line with in vitro findings. Different routes of administration have been demonstrated for using in bacteriophage therapy. A major restriction is that no well-designed clinical survey has been performed, so, physicians and researchers cannot evade bacteriophages in the search as a novel therapy for infectious diseases. Nevertheless, a better development of phage therapy as a usual alternative to strictly chemical-based treatment of bacterial infections in humans will require much greater enterprise than that has so far been the case. Therefore, the bacteriophage may become one of the biggest hopes in the future for the treatment of resistant bacteria that do not respond to the treatment. However, to achieve commercial applications in medical problems, more research and development are needed.

\section{Disclosure}

The authors report no conflicts of interest in this work.

\section{References}

1. Rex JH, Talbot GH, Goldberger MJ, et al. Progress in the fight against multidrug-resistant bacteria 2005-2016: modern noninferiority trial designs enable antibiotic development in advance of epidemic bacterial resistance. Clin Infect Dis. 2017;65:141-146. doi:10.1093/cid/ $\operatorname{cix} 246$
2. Tacconelli E, Carrara E, Savoldi A, et al. Discovery, research, and development of new antibiotics: the WHO priority list of antibiotic-resistant bacteria and tuberculosis. Lancet Infect Dis. 2018;18:318-327. doi:10.1016/S1473-3099(17)30753-3

3. Bahramian A, Shariati A, Azimi T, et al. First report of New Delhi metallo- $\beta$-lactamase-6 (NDM-6) among Klebsiella pneumoniae ST147 strains isolated from dialysis patients in Iran. Infect Genet Evol. 2019b;69:142-145. doi:10.1016/j. meegid.2019.01.030

4. Freire-Moran L, Aronsson B, Manz C, et al. Critical shortage of new antibiotics in development against multidrug-resistant bacteria - time to react is now. Drug Resist Updat. 2011;14:118-124. doi:10.1016/j.drup.2011.02.003

5. Jain S. Emergence of colistin resistance among gram negative bacteria in urinary tract infections from super specialty hospital of North India. Int $J$ Infect Dis. 2018;73:133. doi:10.1016/j. ijid.2018.04.3716

6. Mohebi S, Hossieni Nave H, Norouzi A, Kandehkar Gharaman M, Taati Moghadam M. Detection of extended spectrum beta lactamases on class I integron in escherichia coli isolated from clinical samples. J Mazandaran Univ Med Sci. 2016;26:66-76.

7. Fair RJ, Tor Y. Antibiotics and bacterial resistance in the $21 \mathrm{st}$ century. Perspect Medicin Chem. 2014;6:S14459. doi:10.4137/ PMC.S14459

8. Hadizadeh M, Norouzi A, Taghadosi R, et al. Prevalence of qnr, intI, and intII genes in extendedspectrum beta-lactamase (ESBL)-producing Escherichia coli isolated from clinical samples in Iran. Trop J Pharm Res. 2017;16:141-147.

9. Yang Y-S, Wei W, Hu X-X, et al. Evolution and antibacterial evaluation of 8-hydroxy-cycloberberine derivatives as a novel family of antibacterial agents against MRSA. Molecules. 2019;24:984. doi:10.3390/molecules24050984

10. Boluki E, Kazemian H, Peeridogaheh H, et al. Antimicrobial activity of photodynamic therapy in combination with colistin against a pan-drug resistant Acinetobacter baumannii isolated from burn patient. Photodiagnosis Photodyn Ther. 2017;18:1-5. doi:10.1016/j.pdpdt.2017.01.003

11. Khan SN, Khan AU. Breaking the spell: combating multidrug resistant 'superbugs'. Front Microbiol. 2016;7:174. doi:10.3389/ fmicb.2016.00174

12. Sharahi JY, Azimi T, Shariati A, Safari H, Tehrani MK, Hashemi A. Advanced strategies for combating bacterial biofilms. J Cell Physiol. 2019;234:14689-14708. doi:10.1002/jcp.v234.9

13. Wright GD, Sutherland AD. New strategies for combating multidrug-resistant bacteria. Trends Mol Med. 2007;13:260-267. doi:10.1016/j.molmed.2007.04.004

14. Burrowes B, Harper DR, Anderson J, Mcconville M, Enright MC. Bacteriophage therapy: potential uses in the control of antibiotic-resistant pathogens. Expert Rev Anti Infect Ther. 2011;9:775-785. doi:10.1586/eri.11.90

15. Kamal F, Dennis JJ. Burkholderia cepacia complex Phage-Antibiotic Synergy (PAS): antibiotics stimulate lytic phage activity. Appl Environ Microbiol. 2014;02850-14.

16. Knezevic P, Curcin S, Aleksic V, Petrusic M, Vlaski L. Phageantibiotic synergism: a possible approach to combatting Pseudomonas aeruginosa. Res Microbiol. 2013;164:55-60. doi:10.1016/j.resmic.2012.08.008

17. Mapes AC, Trautner BW, Liao KS, Ramig RF. Development of expanded host range phage active on biofilms of multi-drug resistant Pseudomonas aeruginosa. Bacteriophage. 2016;6: e1096995. doi:10.1080/21597081.2015.1096995

18. Yin S, Huang G, Zhang Y, et al. Phage Abp1 rescues human cells and mice from infection by pan-drug resistant Acinetobacter baumannii. Cell Physiol Biochem. 2017;44:2337-2345. doi: $10.1159 / 000486117$ 
19. Hankin EH. L'action bactericide des eaux de la Jumna et du Gange sur le vibrion du cholera. Ann Inst Pasteur. 1896;10:11.

20. Twort FW. Further investigations on the nature of ultra-microscopic viruses and their cultivation. Epidemiol Infect. 1936;36:204-235.

21. D'Herelle M. Sur un microbe invisible antagoniste des bacilles dysentériques. Acta Kravsi; 1961.

22. Abedon ST, Kuhl SJ, Blasdel BG, Kutter EM. Phage treatment of human infections. Bacteriophage. 2011;1:66-85. doi:10.4161/ bact.1.2.15845

23. Gelman D, Eisenkraft A, Chanishvili N, Nachman D, Glazer SC, Hazan R. The history and promising future of phage therapy in the military service. J Trauma Acute Care Surg. 2018;85:S18S26. doi:10.1097/TA.0000000000001809

24. Cisek AA, Dąbrowska I, Gregorczyk KP, Wyżewski Z. Phage therapy in bacterial infections treatment: one hundred years after the discovery of bacteriophages. Curr Microbiol. 2017;74:277-283. doi:10.1007/s00284-016-1166-x

25. Salmond GP, Fineran PC. A century of the phage: past, present and future. Nat Rev Microbiol. 2015;13:777. doi:10.1038/nrmicro3564

26. Kutter E, Vos DE, Gvasalia D, et al. Phage therapy in clinical practice: treatment of human infections. Curr Pharm Biotechnol. 2010;11:69-86. doi:10.2174/138920110790725401

27. Wittebole X, Roock DE, Opal SM. A historical overview of bacteriophage therapy as an alternative to antibiotics for the treatment of bacterial pathogens. Virulence. 2014;5:226-235. doi:10.4161/viru.25991

28. Pieterse L, Powers A, Pride D, Van Onselen L, Leone GE, Richardson PE. Investigating the lytic staphylococcus aureus bacteriophage reservoir amongst a south carolina university population: discovery, characterization, and identification of a potential bacteriophage treatment for methicillin-resistant staphylococcus aureus. J S C Acad Sci. 2018;16:8.

29. Pincus NB, Reckhow JD, Saleem D, Jammeh ML, Datta SK, Myles IA. Strain specific phage treatment for Staphylococcus aureus infection is influenced by host immunity and site of infection. PLoS One. 2015;10:e0124280. doi:10.1371/journal. pone.0124280

30. Pires DP, Boas DV, Sillankorva S, Azeredo J. Phage therapy: a step forward in the treatment of Pseudomonas aeruginosa infections. J Virol. 2015;00385-15.

31. Lepelletier D, Berthelot P, Lucet J-C, et al. French recommendations for the prevention of 'emerging extensively drug-resistant bacteria'(eXDR) cross-transmission. $J$ Hosp Infect. 2015;90:186-195. doi:10.1016/j.jhin.2015.04.002

32. Tan SY, Tatsumura Y. Alexander Fleming (1881-1881): discoverer of penicillin. Singapore medical journal. 2015;56:399.

33. Bodier-Montagutelli E, Morello E, L'Hostis G, et al. Inhaled phage therapy: a promising and challenging approach to treat bacterial respiratory infections. Expert Opin Drug Deliv. 2017;14:959-972. doi:10.1080/17425247.2017.1252329

34. Penesyan A, Gillings M, Paulsen IT. Antibiotic discovery: combatting bacterial resistance in cells and in biofilm communities. Molecules. 2015;20:5286-5298. doi:10.3390/molecules20045286

35. Blaskovich MA, Pitt ME, Elliott AG, Cooper MA. Can octapeptin antibiotics combat extensively drug-resistant (XDR) bacteria? Expert Rev Anti Infect Ther. 2018;16:485-499. doi:10.1080/ 14787210.2018.1483240

36. Dorval Courchesne NM, Parisien A, Lan CQ. Production and application of bacteriophage and bacteriophage-encoded lysins. Recent Pat Biotechnol. 2009;3:37-45. doi:10.2174/ 187220809787172678

37. Hagens S, Loessner MJ. Application of bacteriophages for detection and control of foodborne pathogens. Appl Microbiol Biotechnol. 2007;76:513-519. doi:10.1007/s00253-007-1031-8
38. Nagel TE, Chan BK, De Vos D, et al. The developing world urgently needs phages to combat pathogenic bacteria. Front Microbiol. 2016;7:882. doi:10.3389/fmicb.2016.00882

39. Lood R, Winer BY, Pelzek AJ, et al. Novel phage lysins capable of killing the multidrug resistant Gram-negative bacterium Acinetobacter baumannii in a mouse sepsis model. Antimicrob Agents Chemother. 2015;04641-14.

40. Nakonieczna A, Cooper CJ, Gryko R. Bacteriophages and bacteriophage-derived endolysins as potential therapeutics to combat Gram-positive spore forming bacteria. $J$ Appl Microbiol. 2015;119:620-631. doi:10.1111/jam.12881

41. Pereira C, Moreirinha C, Teles L, et al. Application of phage therapy during bivalve depuration improves Escherichia coli decontamination. Food Microbiol. 2017;61:102-112. doi:10.1016/j.fm.2016.09.003

42. Pabary R, Singh C, Morales S, et al. Anti-pseudomonal bacteriophage reduces infective burden and inflammatory response in murine lung. Antimicrob Agents Chemother. 2015;01426-15.

43. Górski A, Międzybrodzki R, Weber-Dąbrowska B, et al. Phage therapy: combating infections with potential for evolving from merely a treatment for complications to targeting diseases. Front Microbiol. 2016;7:1515. doi:10.3389/fmicb.2016.01515

44. Nobrega FL, Costa AR, Kluskens LD, Azeredo J. Revisiting phage therapy: new applications for old resources. Trends Microbiol. 2015;23:185-191. doi:10.1016/j.tim.2015.01.006

45. Shen G-H, Wang J-L, Wen F-S, et al. Isolation and characterization of $\varphi \mathrm{km} 18 \mathrm{p}$, a novel lytic phage with therapeutic potential against extensively drug resistant Acinetobacter baumannii. PLoS One. 2012;7:e46537. doi:10.1371/journal.pone.0046537

46. Bertozzi Silva J, Storms Z, Sauvageau D. Host receptors for bacteriophage adsorption. FEMS Microbiol Lett. 2016;363.

47. Woźnica WM, Bigos J, Łobocka MB. Lysis of bacterial cells in the process of bacteriophage release-canonical and newly discovered mechanisms. Postepy Hig Med Dosw (Online). 2015;69:114-126.

48. Drulis-Kawa Z, Majkowska-Skrobek G, Maciejewska B. Bacteriophages and phage-derived proteins-application approaches. Curr Med Chem. 2015;22:1757-1773. doi:10.2174/ 0929867322666150209152851

49. Dewey JS, Savva CG, White RL, Vitha S, Holzenburg A, Young R. Micron-scale holes terminate the phage infection cycle. Proc Natl Acad Sci. 2010;107:2219-2223. doi:10.1073/ pnas.0914030107

50. Shi Y, Yan Y, Ji W, et al. Characterization and determination of holin protein of Streptococcus suis bacteriophage SMP in heterologous host. Virol J. 2012;9:70. doi:10.1186/1743-422X-9-70

51. Pang T, Savva CG, Fleming KG, Struck DK, Young R. Structure of the lethal phage pinhole. Proc Natl Acad Sci. 2009;106:18966-18971. doi:10.1073/pnas.0907941106

52. Donovan DM, Foster-Frey J. LambdaSa2 prophage endolysin requires Cpl-7-binding domains and amidase-5 domain for antimicrobial lysis of streptococci. FEMS Microbiol Lett. 2008;287:22-33. doi:10.1111/fml.2008.287.issue-1

53. Linden SB, Zhang H, Heselpoth RD, et al. Biochemical and biophysical characterization of PlyGRCS, a bacteriophage endolysin active against methicillin-resistant Staphylococcus aureus. Appl Microbiol Biotechnol. 2015;99:741-752. doi:10.1007/ s00253-014-5930-1

54. Tran TA, Struck DK, Young R. Periplasmic domains define holin-antiholin interactions in T4 lysis inhibition. $J$ Bacteriol. 2005;187:6631-6640. doi:10.1128/JB.187.19.6631-6640.2005

55. Catalao MJ, Gil F, Moniz-Pereira J, Sao-Jose C, Pimentel M. Diversity in bacterial lysis systems: bacteriophages show the way. FEMS Microbiol Rev. 2013;37:554-571. doi:10.1111/15746976.12006 
56. Frias MJ, Melo-Cristino J, Ramirez M. The autolysin LytA contributes to efficient bacteriophage progeny release in Streptococcus pneumoniae. J Bacteriol. 2009;191:5428-5440. doi:10.1128/JB.00477-09

57. De Smet J, Hendrix H, Blasdel BG, Danis-Wlodarczyk K, Lavigne R. Pseudomonas predators: understanding and exploiting phage-host interactions. Nat Rev Microbiol. 2017;15:517. doi:10.1038/nrmicro.2017.61

58. Rozema EA, Stephens TP, Bach SJ, et al. Oral and rectal administration of bacteriophages for control of Escherichia coli O157: H7 in feedlot cattle. J Food Prot. 2009;72:241-250. doi:10.4315/ 0362-028X-72.2.241

59. Ryan EM, Gorman SP, Donnelly RF, Gilmore BF. Recent advances in bacteriophage therapy: how delivery routes, formulation, concentration and timing influence the success of phage therapy. J Pharm Pharmacol. 2011;63:1253-1264. doi:10.1111/ j.2042-7158.2011.01324.x

60. Vieira A, Silva Y, Cunha A, Gomes N, Ackermann H-W, Almeida A. Phage therapy to control multidrug-resistant Pseudomonas aeruginosa skin infections: in vitro and ex vivo experiments. Eur J Clin Microbiol Infect Dis. 2012;31:3241-3249. doi:10.1007/s10096-012-1691-x

61. Regeimbal JM, Jacobs AC, Corey BW, et al. Personalized therapeutic cocktail of wild environmental phages rescues mice from A. baumannii wound infections. Antimicrob Agents Chemother. 2016;02877-15.

62. Jado I, López R, García E, Fenoll A, Casal J, García P. Phage lytic enzymes as therapy for antibiotic-resistant Streptococcus pneumoniae infection in a murine sepsis model. $J$ Antimicrob Chemother. 2003;52:967-973. doi:10.1093/jac/dkg485

63. Biswas B, Adhya S, Washart P, et al. Bacteriophage therapy rescues mice bacteremic from a clinical isolate of vancomycin-resistant Enterococcus faecium. Infect Immun. 2002;70:204-210. doi:10.1128/IAI.70.1.204-210.2002

64. Vinodkumar C, Kalsurmath S, Neelagund Y. Utility of lytic bacteriophage in the treatment of multidrug-resistant Pseudomonas aeruginosa septicemia in mice. Indian J Pathol Microbiol. 2008;51:360. doi:10.4103/0377-4929.42511

65. Danelishvili L, Young LS, Bermudez LE. In vivo efficacy of phage therapy for Mycobacterium avium infection as delivered by a nonvirulent mycobacterium. Microb Drug Resist. 2006;12:1-6. doi:10.1089/mdr.2006.12.1

66. Deng L, Yang Z, Gong Y, et al. Therapeutic effect of phages on extensively drug-resistant Acinetobacter baumannii-induced sepsis in mice. Zhonghua Shao Shang Za Zhi. 2016;32:523-528. doi:10.3760/cma.j.issn.1009-2587.2016.09.003

67. Morello E, Saussereau E, Maura D, Huerre M, Touqui L, Debarbieux L. Pulmonary bacteriophage therapy on Pseudomonas aeruginosa cystic fibrosis strains: first steps towards treatment and prevention. PLoS One. 2011;6:e16963.

68. Schooley RT, Biswas B, Gill JJ, et al. Development and use of personalized bacteriophage-based therapeutic cocktails to treat a patient with a disseminated resistant Acinetobacter baumannii infection. Antimicrob Agents Chemother. 2017;61:e00954-17. doi:10.1128/AAC.00954-17

69. Ooi ML, Drilling AJ, Morales S, et al. Safety and tolerability of bacteriophage therapy for chronic rhinosinusitis due to staphylococcus aureus. JAMA Otolaryngol Head Neck Surg. 2019;145:723. doi:10.1001/jamaoto.2019.1191

70. Fish R, Kutter E, Wheat G, Blasdel B, Kutateladze M, Kuhl S. Bacteriophage treatment of intransigent diabetic toe ulcers: a case series. J Wound Care. 2016;25:S27-S33. doi:10.12968/ jowc.2016.25.Sup7.S27

71. Chan BK, Turner PE, Kim S, Mojibian HR, Elefteriades JA, Narayan D. Phage treatment of an aortic graft infected with Pseudomonas aeruginosa. Evol Med Public Health. 2018;2018:60-66. doi:10.1093/emph/eoy005
72. Jennes S, Merabishvili M, Soentjens P, et al. Use of bacteriophages in the treatment of colistin-only-sensitive Pseudomonas aeruginosa septicaemia in a patient with acute kidney injury - a case report. Crit Care. 2017;21:129. doi:10.1186/s13054-017-1709-y

73. Letkiewicz S, Międzybrodzki R, Fortuna W, Weber-Dąbrowska B, Górski A. Eradication of Enterococcus faecalis by phage therapy in chronic bacterial prostatitis - case report. Folia Microbiol (Praha). 2009;54:457. doi:10.1007/s12223-009-0064-z

74. Rhoads D, Wolcott R, Kuskowski MA, Wolcott B, Ward L, Sulakvelidze A. Bacteriophage therapy of venous leg ulcers in humans: results of a Phase I safety trial. J Wound Care. 2009;18:237-243. doi:10.12968/jowc.2009.18.6.42801

75. Wright A, Hawkins C, Änggård E, Harper D. A controlled clinical trial of a therapeutic bacteriophage preparation in chronic otitis due to antibiotic-resistant Pseudomonas aeruginosa; a preliminary report of efficacy. Clin Otolaryngol. 2009;34:349-357. doi:10.1111/coa.2009.34.issue-4

76. Schwarz S, Johnson AP. Transferable resistance to colistin: a new but old threat. J Antimicrob Chemother. 2016;71:2066-2070. doi:10.1093/jac/dkw274

77. Azimi T, Shariati A, Fallah F, et al. Mycobacterium tuberculosis genotyping using MIRU-VNTR typing. J Mazandaran Univ Med Sci. 2017;27:40-48.

78. Falagas ME, Koletsi PK, Bliziotis IA. The diversity of definitions of multidrug-resistant (MDR) and pandrug-resistant (PDR) Acinetobacter baumannii and Pseudomonas aeruginosa. $J$ Med Microbiol. 2006;55:1619-1629. doi:10.1099/jmm.0.46747-0

79. Magiorakos AP, Srinivasan A, Carey R, et al. Multidrug-resistant, extensively drug-resistant and pandrug-resistant bacteria: an international expert proposal for interim standard definitions for acquired resistance. Clin Microbiol Infect. 2012;18:268-281. doi:10.1111/j.1469-0691.2011.03570.x

80. Siegel JD, Rhinehart E, Jackson M, Chiarello L. Management of multidrug-resistant organisms in health care settings, 2006. Am J Infect Control. 2007;35:S165-S193. doi:10.1016/j.ajic.2007.10.006

81. Falagas ME, Karageorgopoulos DE. Pandrug resistance (PDR), extensive drug resistance (XDR), and multidrug resistance (MDR) among Gram-negative bacilli: need for international harmonization in terminology. Clin Infect Dis. 2008;46:1121-1122. doi:10.1086/587996

82. Kuo L-C, Teng L-J, Yu C-J, Ho S-W, Hsueh P-R. Dissemination of a clone of unusual phenotype of pandrug-resistant Acinetobacter baumannii at a university hospital in Taiwan. J Clin Microbiol. 2004;42:1759-1763. doi:10.1128/ jcm.42.4.1759-1763.2004

83. Kuo L-C, Yu C-J, Lee L-N, et al. Clinical features of pandrug-resistant Acinetobacter baumannii bacteremia at a university hospital in Taiwan. $J$ Formos Med Assoc. 2003;102:601-606.

84. Bahramian A, Khoshnood S, Shariati A, Doustdar F, Chirani AS, Heidary M. Molecular characterization of the pilS2 gene and its association with the frequency of Pseudomonas aeruginosa plasmid pKlc102 and PaPI-1 pathogenicity island. Infect Drug Resist. 2019a;12:221. doi:10.2147/IDR.S188527

85. Theuretzbacher U. Global antimicrobial resistance in Gram-negative pathogens and clinical need. Curr Opin Microbiol. 2017;39:106-112. doi:10.1016/j.mib.2017.10.028

86. Shariati A, Azimi T, Ardebili A, et al. Insertional inactivation of oprD in carbapenem-resistant Pseudomonas aeruginosa strains isolated from burn patients in Tehran, Iran. New Microbes New Infect. 2018;21:75-80. doi:10.1016/j.nmni.2017.10.013

87. Talbot GH, Bradley J, Edwards JE JR, Gilbert D, Scheld M, Bartlett JG. Bad bugs need drugs: an update on the development pipeline from the antimicrobial availability task force of the infectious diseases society of America. Clin Infect Dis. 2006;42:657-668. doi:10.1086/499819 
88. Dorman SE, Chaisson RE. From magic bullets back to the magic mountain: the rise of extensively drug-resistant tuberculosis. Nat Med. 2007;13:295. doi:10.1038/nm0307-295

89. Sebaihia M, Wren BW, Mullany P, et al. The multidrug-resistant human pathogen Clostridium difficile has a highly mobile, mosaic genome. Nat Genet. 2006;38:779. doi:10.1038/ng1830

90. Ardehali SH, Azimi T, Fallah F, Owrang M, Aghamohammadi N, Azimi L. Role of efflux pumps in reduced susceptibility to tigecycline in Acinetobacter baumannii. New Microbes New Infect. 2019;30.

91. Mcgowan JE JR. Resistance in nonfermenting gram-negative bacteria: multidrug resistance to the maximum. Am J Infect Control. 2006;34:S29-S37. doi:10.1016/j.ajic.2006.05.226

92. Pitout JD, Laupland KB. Extended-spectrum $\beta$-lactamaseproducing Enterobacteriaceae: an emerging public-health concern. Lancet Infect Dis. 2008;8:159-166. doi:10.1016/ S1473-3099(08)70041-0

93. Klein E, Smith DL, Laxminarayan R. Hospitalizations and deaths caused by methicillin-resistant Staphylococcus aureus, United States, 1999-2005. Emerg Infect Dis. 2007;13:1840.

94. Arumugam SN, Rudraradhya AC, Sadagopan S, Sukumaran S, Sambasivam G, Ramesh N. Analysis of susceptibility patterns of pseudomonas aeruginosa and isolation, characterization of lytic bacteriophages targeting multi drug resistant pseudomonas aeruginosa. Biomed Pharmacol J. 2018;11:1105-1117.

95. Rashel M, Uchiyama J, Ujihara T, et al. Efficient elimination of multidrug-resistant Staphylococcus aureus by cloned lysin derived from bacteriophage $\phi \mathrm{MR} 11 . J$ Infect Dis. 2007;196:1237-1247. doi:10.1086/521305

96. Latz S, Kruttgen A, Häfner H, Buhl EM, Ritter K, Horz H-P. Differential effect of newly isolated phages belonging to PB1-like, phiKZ-like and LUZ24-like viruses against multi-drug resistant pseudomonas aeruginosa under varying growth conditions. Viruses. 2017;9:315. doi:10.3390/v9110315

97. Golkar Z, Bagasra O, Jamil N. Experimental phage therapy on multiple drug resistant Pseudomonas aeruginosa infection in mice. J Antivir Antiretrovir. 2013: S10-005. doi, 10.

98. Wang J, Hu B, Xu M, et al. Use of bacteriophage in the treatment of experimental animal bacteremia from imipenem-resistant Pseudomonas aeruginosa. Int J Mol Med. 2006;17:309-317.

99. Jun JW, Shin TH, Kim JH, et al. Bacteriophage therapy of a Vibrio parahaemolyticus infection caused by a multipleantibiotic-resistant O3: K6 pandemic clinical strain. J Infect Dis. 2014;210:72-78. doi:10.1093/infdis/jiu059

100. Pouillot F, Chomton M, Blois H, et al. Efficacy of bacteriophage therapy in experimental sepsis and meningitis caused by a clone O25b: H4-ST131 Escherichia coli strain producing CTX-M-15. Antimicrob Agents Chemother. 2012;56:3568-3575.

101. Wills QF, Kerrigan C, Soothill JS. Experimental bacteriophage protection against Staphylococcus aureus abscesses in a rabbit model. Antimicrob Agents Chemother. 2005;49:1220-1221. doi:10.1128/AAC.49.3.1220-1221.2005

102. Kwiatek M, Mizak L, Parasion S, Gryko R, Olender A, Niemcewicz M. Characterization of five newly isolated bacteriophages active against Pseudomonas aeruginosa clinical strains. Folia Microbiol (Praha). 2015;60:7-14. doi:10.1007/s12223-014-0333-3

103. Peng F, Mi Z, Huang Y, et al. Characterization, sequencing and comparative genomic analysis of vB_AbaM-IME-AB2, a novel lytic bacteriophage that infects multidrug-resistant Acinetobacter baumannii clinical isolates. BMC Microbiol. 2014;14:181. doi:10.1186/14712180-14-181

104. Larche J, Pouillot F, Essoh C, et al. Rapid identification of international multidrug-resistant Pseudomonas aeruginosa clones by multiple-locus variable number of tandem repeats analysis and investigation of their susceptibility to lytic bacteriophages. Antimicrob Agents Chemother. 2012;56:6175-6180.
105. Shokri D, Soleimani-Delfan A, Fatemi SM. Assessment of phage cocktails with extended host range activity against antibiotic resistant strains of Pseudomonas aeruginosa. Comp Clin Path. 2017;26:417-422. doi:10.1007/s00580-016-2394-y

106. Bai C, Liu Y, Mi Z, Tong Y. Potential of the phage depolymerase from a myoviridae bacteriophage vB_AbaM_IME200 against pandrug-resistant acinetobacter Baumannii. In: C60 Translational and Basic Investigations in Pulmonary Infection. American Thoracic Society; 2018:A5488-A5488.

107. Comeau AM, Tetart F, Trojet SN, Prere M-F, Krisch H. Phageantibiotic synergy (PAS): $\beta$-lactam and quinolone antibiotics stimulate virulent phage growth. PLoS One. 2007;2:e799. doi:10.1371/ journal.pone.0000799

108. Djurkovic S, Loeffler JM, Fischetti VA. Synergistic killing of Streptococcus pneumoniae with the bacteriophage lytic enzyme Cpl-1 and penicillin or gentamicin depends on the level of penicillin resistance. Antimicrob Agents Chemother. 2005;49:1225-1228. doi:10.1128/AAC.49.3.1225-1228.2005

109. Kelly D, Mcauliffe O, Ross R, Coffey A. Prevention of Staphylococcus aureus biofilm formation and reduction in established biofilm density using a combination of phage $\mathrm{K}$ and modified derivatives. Lett Appl Microbiol. 2012;54:286-291. doi:10.1111/ lam.2012.54.issue-4

110. Khalifa L, Brosh Y, Gelman D, et al. Targeting Enterococcus faecalis biofilm using phage therapy. Appl Environ Microbiol. 2015;00096-15.

111. Kirby AE. Synergistic action of gentamicin and bacteriophage in a continuous culture population of Staphylococcus aureus. PLoS One. 2012;7:e51017. doi:10.1371/journal.pone.0051017

112. Loeffler J, Fischetti V. Synergistic lethal effect of a combination of phage lytic enzymes with different activities on penicillin-sensitive and-resistant Streptococcus pneumoniae strains. Antimicrob Agents Chemother. 2003;47:375-377. doi:10.1128/AAC.47.1.375-377.2003

113. Oechslin F, Piccardi P, Mancini S, et al. Synergistic interaction between phage therapy and antibiotics clears Pseudomonas aeruginosa infection in endocarditis and reduces virulence. $J$ Infect Dis. 2016;215:703-712.

114. Ryan EM, Alkawareek MY, Donnelly RF, Gilmore BF. Synergistic phage-antibiotic combinations for the control of Escherichia coli biofilms in vitro. FEMS Immunol Med Microbiol. 2012;65:395-398. doi:10.1111/j.1574-695X.2012.00977.x

115. Verma V, Harjai K, Chhibber S. Restricting ciprofloxacin-induced resistant variant formation in biofilm of Klebsiella pneumoniae B5055 by complementary bacteriophage treatment. J Antimicrob Chemother. 2009;64:1212-1218. doi:10.1093/jac/dkp360

116. Yele AB, Thawal ND, Sahu PK, Chopade BA. Novel lytic bacteriophage AB7-IBB1 of Acinetobacter baumannii: isolation, characterization and its effect on biofilm. Arch Virol. 2012;157:1441-1450. doi:10.1007/s00705-012-1320-0

117. Rohde C, Resch G, Pirnay J-P, et al. Expert opinion on three phage therapy related topics: bacterial phage resistance, phage training and prophages in bacterial production strains. Viruses. 2018;10:178. doi:10.3390/v10040178

118. Susskind MM, Wright A, Botstein D. Superinfection exclusion by P22 prophage in lysogens of Salmonella typhimurium: II. Genetic evidence for two exclusion systems. Virology. 1971;45:638-652. doi:10.1016/0042-6822(71)90178-4

119. Drulis-Kawa Z, Majkowska-Skrobek G, Maciejewska B, Delattre A-S, Lavigne R. Learning from bacteriophages-advantages and limitations of phage and phage-encoded protein applications. Curr Protein Pept Sci. 2012;13:699-722. doi:10.2174/ 138920312804871193

120. Labrie SJ, Samson JE, Moineau S. Bacteriophage resistance mechanisms. Nat Rev Microbiol. 2010;8:317. doi:10.1038/ nrmicro2315 
121. Sekulovic O, Ospina Bedoya M, Fivian-Hughes AS, Fairweather NF, Fortier LC. The C lostridium difficile cell wall protein $\mathrm{CwpV}$ confers phase-variable phage resistance. Mol Microbiol. 2015;98:329-342. doi:10.1111/mmi.13121

122. Chapman-Mcquiston E, Wu X. Stochastic receptor expression allows sensitive bacteria to evade phage attack. Part I: experiments. Biophys J. 2008;94:4525-4536. doi:10.1529/ biophysj.107.120212

123. Mahmud RS, Mindubaeva L, Ulyanova V, Khazieva L, Vargas H, Ilinskaya O. Antibacteriophage action of Bacillus altitudinis extracellular ribonuclease. FEBS J. 2016;283:58-123.

124. Chaudhary K. BacteRiophage EXclusion (BREX): a novel antiphage mechanism in the arsenal of bacterial defense system. J Cell Physiol. 2018;233:771-773. doi:10.1002/jcp.25973

125. Hoque MM, Naser IB, Bari SN, Zhu J, Mekalanos JJ, Faruque SM. Quorum regulated resistance of Vibrio cholerae against environmental bacteriophages. Sci Rep. 2016;6:37956. doi:10.1038/srep37956

126. Tan D, Svenningsen SL, Middelboe M. Quorum sensing determines the choice of antiphage defense strategy in Vibrio anguillarum. MBio. 2015;6:e0627-15. doi:10.1128/mBio.00627-15

127. Ofir G, Melamed S, Sberro H, et al. DISARM is a widespread bacterial defence system with broad anti-phage activities. Nat Microbiol. 2018;3:90. doi:10.1038/s41564-017-0051-0

128. Chopin M-C, Chopin A, Bidnenko E. Phage abortive infection in lactococci: variations on a theme. Curr Opin Microbiol. 2005;8:473-479. doi:10.1016/j.mib.2005.06.006

129. Fineran PC, Blower TR, Foulds IJ, Humphreys DP, Lilley KS, Salmond GP. The phage abortive infection system, ToxIN, functions as a protein-RNA toxin-antitoxin pair. Proc Natl Acad Sci. 2009;106:894-899. doi:10.1073/pnas.0808832106

130. Samson JE, Belanger M, Moineau S. Effect of the abortive infection mechanism and type III toxin/antitoxin system AbiQ on the lytic cycle of Lactococcus lactis phages. J Bacteriol. 2013;00296-13.

131. Martínez-Rubio R, QUILES-PUCHALT N, MARTí M, et al. Phage-inducible islands in the Gram-positive cocci. ISME $J$ 2017;11:1029. doi:10.1038/ismej.2016.163

132. Penades JR, Christie GE. The phage-inducible chromosomal islands: a family of highly evolved molecular parasites. Annl Rev Virol. 2015;2:181-201. doi:10.1146/annurev-virology $-031413-085446$

133. Seed KD. Battling phages: how bacteria defend against viral attack. PLoS Pathog. 2015;11:e1004847. doi:10.1371/journal. ppat.1004847
134. Bondy-Denomy J, Garcia B, Strum S, et al. Multiple mechanisms for CRISPR-cas inhibition by anti-CRISPR proteins. Nature. 2015;526:136. doi:10.1038/nature 15254

135. Obeng N, Pratama AA, Van Elsas JD. The significance of mutualistic phages for bacterial ecology and evolution. Trends Microbiol. 2016;24:440-449. doi:10.1016/j.tim.2015.12.009

136. Samson JE, Magadán AH, Sabri M, Moineau S. Revenge of the phages: defeating bacterial defences. Nat Rev Microbiol. 2013;11:675. doi:10.1038/nrmicro3096

137. Tzipilevich E, Habusha M, Ben-Yehuda S. Acquisition of phage sensitivity by bacteria through exchange of phage receptors. Cell. 2017;168:186-199. e12. doi:10.1016/j.cell.2016.12.003

138. Bondy-Denomy J, Pawluk A, Maxwell KL, Davidson AR Bacteriophage genes that inactivate the CRISPR/Cas bacterial immune system. Nature. 2013;493:429. doi:10.1038/nature11723

139. Hynes AP, Rousseau GM, Lemay M-L, et al. An anti-CRISPR from a virulent streptococcal phage inhibits Streptococcus pyogenes Cas9. Nat Microbiol. 2017;2:1374. doi:10.1038/s41564-017-0004-7

140. Landsberger M, Gandon S, Meaden S, et al. Anti-CRISPR phages cooperate to overcome CRISPR-Cas immunity. Cell. 2018;174:908-916. e12. doi:10.1016/j.cell.2018.05.058

141. Seed KD, Lazinski DW, Calderwood SB, Camilli A. A bacteriophage encodes its own CRISPR/Cas adaptive response to evade host innate immunity. Nature. 2013;494:489. doi:10.1038/ nature 11927

142. Örmälä A-M, Jalasvuori M. Phage therapy: should bacterial resistance to phages be a concern, even in the long run? Bacteriophage. 2013;3:e24219. doi:10.4161/bact.24219

143. Pirnay J-P, Blasdel BG, Bretaudeau L, et al. Quality and safety requirements for sustainable phage therapy products. Pharm Res. 2015;32:2173-2179. doi:10.1007/s11095-014-1617-7

144. Oliveira J, Castilho F, Cunha A, Pereira M. Bacteriophage therapy as a bacterial control strategy in aquaculture. Aquacult Int. 2012;20:879-910.

145. Weld RJ, Butts C, Heinemann JA. Models of phage growth and their applicability to phage therapy. $J$ Theor Biol. 2004;227:1-11. doi:10.1016/S0022-5193(03)00262-5

146. Gorski A, Miedzybrodzki R, Borysowski J, et al. Bacteriophage therapy for the treatment of infections. Curr Opin Investig Drugs. 2009;10:766-774.

147. Międzybrodzki R, Borysowski J, Weber-Dąbrowska B, et al. Clinical aspects of phage therapy. Adv Virus Res. 2012. Elsevier

148. Stafford N. Switzerland is to fund complementary therapies for six years while effectiveness is evaluated. BMJ. 2011;35:569-583.
Infection and Drug Resistance

\section{Publish your work in this journal}

Infection and Drug Resistance is an international, peer-reviewed openaccess journal that focuses on the optimal treatment of infection (bacterial, fungal and viral) and the development and institution of preventive strategies to minimize the development and spread of resistance. The journal is specifically concerned with the epidemiology of antibiotic resistance and the mechanisms of resistance development and diffusion in both hospitals and the community. The manuscript management system is completely online and includes a very quick and fair peerreview system, which is all easy to use. Visit http://www.dovepress.com/ testimonials.php to read real quotes from published authors. 